\title{
Time Distribution Mechanism among Kindergarten Children at Home and Its Relationship with the Practice of Healthy Behavior from Mothers' Perspective
}

\author{
Amal AbdulAziz Ismail (Corresponding author) \\ Assist. Professor of Childhood Studies, Faculty of Home Economics, King Abdul-Aziz \\ University
}

Received: December 30, 2016 Accepted: January 13, 2017 Published: February 28, 2017

doi:10.5296/ire.v5i1.10525 URL: http://dx.doi.org/10.5296/ire.v5i1.10525

\begin{abstract}
The current study aimed to identify the time distribution mechanism for the kindergartners at home and its relationship with the practice of healthy behaviors from the perspective of mothers in Jeddah in Saudi Arabia. In order to achieve the objectives of the study, a sample of (513) children was selected; (241) males and (272) females. Two scales have been developed; time distribution and healthy behavior of $\mathrm{KG}$ children. Their reliability and validity were verified. The study results concluded that the time distribution among the sample was as follows; either answering calls or sometimes staying alone and listening to songs. The healthy behavior was low for both males and females- the whole participants. There was a negative relationship between some child activities and healthy behavior which are; playing alone, day sleeping and crying. There was no difference in behaviors depending on the educational level of the parents. Based on the study results, the study recommends that there is a need to raise the level of healthy behavior and change the time distribution among KG children.
\end{abstract}

Keywords: time distribution mechanism, healthy behavior, kindergarten

\section{Introduction}

Early childhood represents the most important stage in human life due to its flexibility, aptitude for learning, growth of various skills and abilities that make up their world with all its experiences. This leads to the development of all the aspects of the different growth. They include epistemic, cognitive, emotional and social aspects which foster the child's imagination and creativity.

Time is the most important available resource for the individual to engage in different life 
activities. This is a worrying factor for all people. With time, the individual acts to reach his goal. If he invests effectively and make the most of it, he will reach the success level in performing his mission. Regarding time, all individuals are equal; No one has extra time than others. This time is limited. It never comes back. No one can buy, rent or sell it. Also, no one can steal, save, store or double it. That's why it has a great value. So an individual needs more attention to plan and manage and control his time, in order to exploit the best use of it to achieve the goals and reach the required level (Beatles, 1999).

The healthy behavior is considered a collective concept for all patterns of behavior and attitudes based on health, disease and the use of medical services. Also the healthy behavior is identified as all the patterns of behavior that aims to develop the health potential of the individual (Mashaan \& khalifa, 1999).

\subsection{The Study Problem}

The life style affects both; the individual and the community health. It has a close association with many of the health problems that have a high occurrence rate in different countries of the world. These behaviors that lead to such problems start since early childhood. It could be prevented if identified and tuned. Securing a healthy and safe environment for children is a top priority in preparing them in mental, spiritual, physical, and social aspects since their early childhood.

The study problem lies in the study of healthy behaviors in young children. These behaviors do not constitute a threat to the physical health only, but it has the implications of psychological and social behaviors as well. That may overlap and conflict with the tasks assigned to the individual and the satisfaction of the social roles expected from him. Therefore, avoiding such behaviors and practices would improve psychological and physical health of the individual, and life in general.

During the visit of the researcher to more than one kindergarten and conducting a survey on children and teachers and meeting some of the children mothers to determine the level of time distribution among children and the way of their healthy behavior, it was noticed that there are many children who have an appropriate healthy behavior while others don't have it. As noted generally these children don't have a mechanism for time distribution, where most of them spend their time in the playing and in the watching TV. That came up with several questions. What is the time distribution level of these children? Will these children have the right healthy behavior? Does healthy behavior vary depending on gender? Hence, the study problem emerged.

\subsection{Research Questions}

a) What is the time distribution order among the $\mathrm{KG}$ children in Jeddah according to gender?

b) What is the healthy behavior level among the KG children in Jeddah according to gender?

c) Is there a relationship between the $\mathrm{KG}$ children time distribution with the healthy behavior in Jeddah? 
d) Does the healthy behavior differ depending on the educational level of the $\mathrm{KG}$ children's parents in Jeddah?

\subsection{Research Significance}

First: the theoretical importance

The study draws its significance through the following points:

a) It tries to detect the healthy behavior level of kindergarten children.

b) The importance of time management as it is emphasized by previous studies.

c) The importance of the targeted category covered by the study sample- the KG children.

d) This study - to the knowledge of the researcher - is the first to tackle such an issue.

e) The researcher hopes that the current study will be a plus to the psychological research on time management field, which may contribute to the adoption of a number of strategies and programs that will help these children manage their time.

The study draws its applied significance through the following:

a) Develop an objective tool to measure the time distribution and healthy behavior of $\mathrm{KG}$ children.

b) In the order of the study results, we could come up with recommendations on building guidelines and preventive programs to assist in the time distribution and healthy behavior improvement for these children.

c) Provide decision-makers with data that will show them the strengths and weaknesses of the children in terms of health.

\subsection{Objectives}

a) Identifying the arrangement mechanism of the time distribution for $\mathrm{KG}$ children in Jeddah Province

b) Identifying the healthy behavior level for KG children.

c) The kindergarten kid's time distribution mechanism and its relationship with possessing healthy behaviors in Jeddah.

d) Make sure that there is a difference in their healthy behavior depending on the educational level of the kid parents in Jeddah.

\subsection{Limitations}

a) Human determiner: The study was applied to KG children aged between 5-6 years.

b) Spatial determiner: The study was applied at the government and private KGs in the province of Jeddah- Saudi Arabia.

c) Time determiner: the study was applied during the first semester of the academic year 2016-2017.

d) Objective determinants: it is determined by the study tools, which are the distribution of time and healthy behavior scale, also determined by responses of mothers on the two scales. 


\subsection{Concepts}

Time Distribution: considered as the psychological structure including a series of behaviors or strategies or successive skills that are used by an individual in an organized and efficient manner in order to achieve a meaningful positive life. It also means controlling the sequence of events according the proper time to complete it (Tuffaha, 2006). And procedurally, it is the degree achieved by the child for this purpose in the prepared scale.

Healthy behavior: from the selection and systems theory, it is a group of behaviors practiced by an individual to maintain an appropriate level of health. The selection and systems theory assess the individual overall health. It is the integrated result of all aspects of the individual's physical, mental, emotional and motor. Considering that individual's health are the body organs functioning in intimacy, properly and in a harmonious way (Smadi \& Al-Smadi, 2011).

\section{Literature Review}

It has been observed from previous studies that most of them tended to tackle time management of university or school students. No one tackled KG children' time management. Also studies addressed the health behavior of university and school students and the elderly people.

Radwan (2001) conducted a study aimed to analyze healthy behavior and attitudes towards health, the study sample was (300) examined, it was used to identify healthy behavior (Stepto, 1991). The results showed the presence of some characteristics of a sample of which there are significant differences between males and females regarding protection from the sun, dental health, eating meat and fruit, adding salt, coffee consumption, the number of meals and the seat belt. While the German sample reached number of (413) students, it showed a comparison between the two samples, and no differences were found between males and females in health problems. The German sample female's participants indicate the existence of health problems more than Syrian female's sample. The Syrians male pointed to a higher health problems than the German male ones.

Muhammed (2004) did a study titled "effective recreational program to acquire some athlete behaviors and environmental awareness for kindergarten children", it was meant to design a recreational program to see its effectiveness on the acquisition of certain athlete behaviors and environmental awareness for KG children. The researcher used the experimental method, and the most important results were that the traditional program applied on the children with the control group did not affect the athlete's time of the environmental research sample, and there was an improvement regarding the children of the experimental group in the dimensional measurement compared to their peers in the control group in terms of the environmental awareness sports.

A study by Mahesh, Joseph, Varma and Jayanthi (2005) about the health assessment for students at the government and private schools student in the city Chennai in India, the study sample consisted of 1200 students, they were selected from 30 schools, chosen randomly, aged between (5-12) years, and the results showed a good health awareness among students 
at the age of 5 years, more than students who do not exceed the age of 12 years, there was also a prevalence of some diseases among those students.

Saleh (2006) discussed food style for elementary school students in Riyadh- KSA- where the study sample consisted of (796) students, the study aimed to identify the food habits for students to create a basic database and design an awareness educational program aimed at raising awareness of the importance of developing healthy habits and their impact on health. The study results have showed that breakfast was the basic meal and that more than $90 \%$ of the students in the sample take fresh fruits and vegetables only twice a week.

Kearns and Gardlner (2007) conducted a study to know about time management strategies and the relationship between the behavior of time management and the level of morale in the United States. The study sample consisted of 375 male and female students. The results showed that one of the strategies of time management is to apply the necessary, appropriate, and efficiency standards on the type of work and stop non-productive activities. There should be a commitment to write down the list of tasks, work to achieve them, and know the reasons for the waste of time. The research also showed that there is a positive relationship between effective time management and morale.

Jaffery (2008) aimed to measure the level of healthy behavior among class three students at the elementary schools in Riyadh. The sample included (1000) students. The results indicate that the sample members have an interest in the following behavioral aspects (they are interested in good appearance and clean clothes, there must be clean toilets either at home or school, sitting properly for study, participating in sports and recreational activities offered by the school, and participating in sports activities to feel the happiness and satisfaction). They have no attention to the following behavioral aspects (interested in sleep and rest for sufficient hours, drinking cold or hot drinks between meals, conducting a medical examination before joining the school, knowing the effect of exercise on the body, and interested in learning how to pick up objects and carry them from the ground).

Aliah (2008) carried out a study that aimed to identify the time management school for students in grade eleven in Madaba in Jordan, and its relationship to gender and academic specialization. The study sample consisted of (420) students. The study tool was a questionnaire composed of (25) items to measure the time-management skills. The results of the study showed that the most important time management related to academic habits as expressed by the students is: attending classes, reviewing the whole subject at the night before exam, and increasing the number of study hours when the exam is announced. The results showed that no differences are attributed to specialization, but there are significant differences in favor of females to males.

Emine and Dundar (2011) conducted a study aimed to investigate the relationship between self-esteem and the practice of risky health behaviors. The sample of teenagers reached (1361) in Adiyaman in Turkey. The study found that age, grade, gender, self-esteem and the level of school performance had a significant impact on the level of practice of precarious risky health behavior. The study confirmed the need to spread health awareness through the practice of physical activity, proper nutrition and various methods of hygiene. 
Al-Emamy (2011) did a study aimed at exploring the level of health awareness survey and the degree of health practices of basic school students at the schools of the Governorate of Ma'an. The study population consisted of all students in the fifth, sixth and seventh basic educational grades. The study tool included personal health and safety areas, general health and disease prevention, environmental health, and positive health. The study results showed that the level of health awareness and the degree of health practices among elementary students were high on the four areas of the tool. As the results showed, there is existence of impact differences of gender on both the level of health awareness and the degree of health practices in favor of females on the four areas of the tool.

Khalifa (2012) did a study which tackled the effect of some family variables on time management habits in the first grade secondary students in the province of Madaba, Jordan. The study sample consisted of (420) students. The tool was a questionnaire composed of 20 paragraphs. The study results showed that there were no statistically significant differences between the average of time management differences attributed to the father's culture or the number of house rooms. There was existence of differences in habits of study time management attributed to the number of family members and in favor of the category (9-7).

Saleh and Saleh (2013) conducted a study aimed at identifying the procrastination and its relationship with time management for the students of the Faculty of Education at the University of Qadisiyah. The total number of respondents was (368) students. To measure this goal, an academic unit for procrastination was established. The results indicated that education students don't have academic procrastination and they suffer a lack of time management.

Al-Suiof (2014) did a study on time management strategies to the students of the Faculty of Educational Sciences at the University of Jordan. The tool developed by the researcher consisted of (45) items listed into four levels to choose validity and reliability. The study sample consisted of 237 male and female students at the undergraduate and graduate stages. The study found no differences in the use of time management strategies attributed to educational level and gender. There was a presence of significant differences in the students' use of time management strategies attributable to the rate of cumulative and in favor of the rate of (V. Good and Excellent).

Saber (2015) discussed a study of time management at university students and its relationship with some variables. The study sample consisted of 260 students selected from (6) faculties related to science and humanities at the University of Sulaymaniyah in Iraq. The study results showed that the level of time management of university students is average, and had no differences in the management of time depending on the variables covered by the research.

It is noticed form the review of previous studies that most of them had addressed adults and school students, whereas the current study is concerned with KG children, which was not tackled by previous studies.

\section{Methodology and Procedures}

The descriptive analytical correlative method was used due to its suitability to the topic of the 
study. The study population consisted of all KG children in the province of Jeddah- KSA, both in government or private KGs. The respondent of this study are the mothers. KGs were selected in a random manner. It was limited to 550 children to apply the study. After deleting incomplete mothers' response, the number of final sample is (513) children. This includes (241) males and (272) females. The children are aged (5-6), the number five-year children were (283), and six-year children were (230). The following table shows the distribution of the study sample according to the main variables.

Table 1. Distribution of study sample according to demographic variables

\begin{tabular}{llcc}
\hline & \multicolumn{1}{c}{ The variable } & Children number & The sample percentage \\
\hline The kindergarten type & Governmental & 281 & $54.8 \%$ \\
& private & 232 & $45.2 \%$ \\
\hline The father's educational level & Less than secondary & 34 & $6.6 \%$ \\
& secondary & 110 & $21.4 \%$ \\
& Bachelor degree & 314 & $61.2 \%$ \\
& Postgraduate degree & 55 & $10.7 \%$ \\
\hline The mother's educational level & Less than secondary & 34 & $6.6 \%$ \\
& secondary & 112 & $21.8 \%$ \\
& Bachelor degree & 323 & $63 \%$ \\
& Postgraduate degree & 44 & $8.6 \%$ \\
\hline the child order among his siblings & $1-3$ siblings & 378 & $73.7 \%$ \\
& $4-6$ siblings & 122 & $23.8 \%$ \\
& 7 and older & 13 & $2.5 \%$ \\
\hline Siblings number & $1-3$ siblings & 345 & $67.3 \%$ \\
& $4-6$ siblings & 148 & $28.2 \%$ \\
& 7 and older & 20 & $3.8 \%$ \\
\hline
\end{tabular}

\section{Study Tools}

To achieve the objectives of this study, the following tools were used:

\subsection{First, the Time Distribution Scale}

The current scale aims to know the KG time distribution during the day from the perspective of mothers. Therefore, this scale has been the developed in order to show how it is distributed among KG children. The following previous studies and references were used: (Hilal \& AlHusseini, 2004; Al-Alaaq, 2009; Sabir, 2015; Khalifa, 2012; Bakhit, 2008). The scale first version consists of (29) items and each paragraph includes six choices, which are (more than three hours and was given 6 , and between three hours and two hours and was given (5), and less than two hours and more than an hour and were given (4), and less than an hour to half an hour and were given (3), less than half an hour a day and were given (2), and does not take 
time and given (1). At the end of the scale there is an open option: that if there were any other things that take time during the day, it is recommended to be mentioned.

To ensure the scale appropriation for the study, its objectives and sample, the psychometric characteristics were emphasized as follows:

Validity of reviewers: the first draft of the tool was distributed among (10) faculty members and specialists in Saudi Arabia and Jordan. They are specialists in psychology, kindergartens and administration. They were asked to give their opinion on the draft and its relevance to the paragraphs, the suitability of the Saudi Arabia environment, and to add any comments concerning amendments. Seven reviewers judged the validity of paragraphs. Based on the opinion of the reviewers, (3) paragraphs were modified and (29) paragraphs were finalized.

Internal Validity: The reliability of the tool was applied on a sample of (35(children from KGs or from the community. The correlation coefficients were calculated by measuring the performance of the study sample and each paragraph related to time distribution. As a child in kindergarten from outside the study sample and within the community, ranged link patterns the coefficient of the paragraphs ranged between $(0.43-0.68)$. This indicates the reliability of the tool.

Tool Reliability: The reliability of the tool was applied on a sample of (35(children from KGs or from the community. To confirm this validity, it was repeated by a two-week gap. The total reliability coefficient was $(0.77)$ and was in accordance with to offset the Cronbach's alpha reliability coefficient. It reached internal consistency $(0.72)$, which shows the results were up to the mark and scale had advantage of varying fixed values and showed the proper use of this scale.

\section{The tool Correction:}

All the scale paragraphs indicate the distribution of time mechanism in the child from the mother's point of view. To explain the answers obtained by the parent, it came as follows:

The term is used to explain the degree to which you get by the parent on average paragraph where the term $=$ greater value -smaller value $/$ number of values, the highest option - the lowest option $=6-1=5$. Then split the difference on a number of levels that have been selected and the number ( 3 ) as follows: $5 / 3=1.67$. It is then added 1.67 to a minimum for each category.

a) The degree of (1-2.67) for the mean of single paragraph indicates a low level of the style used in the distribution of time for the activity.

b) The degree of (2.68-4.33) for the mean of single paragraph indicates the average level of the style used in the distribution of time for the activity.

c) The degree of (4.34-6) for the mean of single paragraph indicates a high level of style used in the distribution of time for the activity.

\subsection{Second: The Healthy Behavior Practice Scale}

This scale was developed to detect the significant health and behavioral practices exercised 
by the child to maintain his health from his mother's perspective. The scale included (40) paragraphs. Those paragraphs were taken from previous studies, they are: (smadi \& Smadi, 2011; Ahmed al-Janabi \& Tufaha, 2008; Shukri, 1999). It has been placed in front of each paragraph three options (3) to be implemented and given him, (2) sometimes implemented and given to him and (1) is not implemented and given him. To ensure an appropriate measure of the study objectives; it has been appointed to make sure of the psychometric characteristics. The scale has no dimensions.

1. Validity (reviewers): the first draft of the tool was distributed among (10) faculty members and specialists in Saudi Arabia. They are specialists in psychology and kindergartens. They were asked to give their opinion on the draft and its relevance to the paragraphs, the suitability of the Saudi Arabia environment, and to add any comments concerning amendments. Seven reviewers judged the validity of paragraphs. Based on the opinion of the reviewers, (8) paragraphs were modified.

2. Tool Validity: the correlation coefficients were calculated the sample scoping study individual performance on each paragraph of the time distribution scale for the kindergarten child through the application of the scale on the exploratory (35) of the total sample. As a child in kindergarten from outside the study sample and within the community, ranged link patterns coefficient paragraphs with a total score of (0.49-0.81), indicating on taking advantage of the scale internal construction honestly.

3. The tool correction: The responder for this measure is the mother herself, but the interpretation of the answers received by the child as follows: is used term to explain the degree to which the child gets from a mother's point of view on the average paragraph where the term = greater value -smaller value / number of values, the highest option - lowest option $=3-1=2$, Then split the difference on a number of levels that have been selected and the number (3) as follows: $2 / 3=0.67$, It is then added 0.67 to a minimum for each category.

- The degree of (1-1.67) for the mean of single paragraph indicates a low level of low health behavior.

- The degree of (1.68-2.33) for the mean of single paragraph indicates the average level of the average healthy behavior.

- The degree of (2.34-3) for the mean of single paragraph indicates a high level of highhealthy behavior.

\section{Results}

The first question: What is the time distribution order among the KG children in Jeddah according to gender?

To answer this question the arithmetic means and standard deviations regarding time distribution were calculated from mothers' point of view, and the sample's point of views according to gender. Table 2 shows the results. 
Table 2. The arithmetic means and standard deviations among children in time distribution level according to gender

\begin{tabular}{|c|c|c|c|c|c|c|c|c|c|c|}
\hline \multirow[t]{2}{*}{ No } & \multirow[t]{2}{*}{ Paragraph } & \multicolumn{3}{|l|}{ Males } & \multicolumn{3}{|c|}{ Females } & \multicolumn{3}{|l|}{ Total } \\
\hline & & Mean & St. D & ranking & Mean & St. D & ranking & Mean & St. D & ranking \\
\hline 1 & $\begin{array}{l}\text { Watching } \\
\text { the TV all } \\
\text { the day }\end{array}$ & 2.97 & 1.202 & 25 & 2.79 & 11.241 & 25 & 2.87 & 1.225 & 25 \\
\hline 2 & $\begin{array}{l}\text { Internet } \\
\text { use, songs, } \\
\text { games and } \\
\text { applications } \\
\text { through the } \\
\text { entire day }\end{array}$ & 3.96 & 1.687 & 8 & 3.74 & 1.585 & 19 & 3.84 & 1.635 & 18 \\
\hline 3 & $\begin{array}{l}\text { Answer } \\
\text { calls during } \\
\text { the day } \\
\text { (parents, } \\
\text { relatives, } \\
\text { friends, ...) }\end{array}$ & 5.61 & .902 & 1 & 5.42 & 11.097 & 1 & 5.51 & 1.014 & 1 \\
\hline 4 & $\begin{array}{l}\text { Playing } \\
\text { with the } \\
\text { phone or } \\
\text { using it as a } \\
\text { game } \\
\text { during the } \\
\text { day }\end{array}$ & 4.95 & 1.422 & 55 & 4.85 & 1.475 & 7 & 4.89 & 1.450 & \\
\hline 5 & $\begin{array}{l}\text { Playing } \\
\text { computer } \\
\text { (any } \\
\text { applications } \\
\text { or } \\
\text { programs } \\
\text { for } \\
\text { children) }\end{array}$ & 4.49 & 1.489 & 33 & 4.32 & 1.576 & 13 & 4.40 & 1.536 & 14 \\
\hline 6 & $\begin{array}{l}\text { Playing ball } \\
\text { or playing } \\
\text { with game }\end{array}$ & 3.20 & 1.341 & 24 & 3.33 & 1.364 & 22 & 3.27 & 1.354 & 23 \\
\hline 7 & $\begin{array}{l}\text { Playing } \\
\text { alone }\end{array}$ & 4.29 & 1.497 & 15 & 4.25 & 1.455 & 16 & 4.27 & 1.474 & 16 \\
\hline 8 & $\begin{array}{l}\text { Playing } \\
\text { with others }\end{array}$ & 2.43 & 1.359 & 27 & 2.60 & 1.405 & 27 & 2.52 & 1.385 & 27 \\
\hline 9 & $\begin{array}{l}\text { Talking } \\
\text { with the } \\
\text { parents or } \\
\text { sit between } \\
\text { family } \\
\text { groups } \\
\text { during the } \\
\text { day }\end{array}$ & 2.27 & 1.384 & 28 & 2.15 & 1.276 & 28 & 2.21 & 1.328 & 28 \\
\hline 10 & Trips & 3.37 & 2.000 & 22 & 3.20 & 1.816 & 23 & 3.28 & 1.905 & 22 \\
\hline
\end{tabular}




\begin{tabular}{|c|c|c|c|c|c|c|c|c|c|c|}
\hline No & Paragraph & Males & & & Femal & & & Total & & \\
\hline 11 & $\begin{array}{l}\text { Hanging } \\
\text { out with } \\
\text { friends }\end{array}$ & 4.23 & 1.975 & 77 & 4.38 & 1.936 & 12 & 4.31 & 1.954 & 15 \\
\hline 12 & $\begin{array}{l}\text { Staying } \\
\text { alone for } \\
\text { sometimes }\end{array}$ & 5.30 & 1.070 & 2 & 5.23 & 1.126 & 3 & 5.26 & 1.100 & 2 \\
\hline 13 & Day sleep & 4.70 & 1.629 & 9 & 4.51 & 1.648 & 10 & 4.60 & 1.640 & 9 \\
\hline 14 & Night sleep & 1.05 & .415 & 29 & 1.05 & .409 & 29 & 1.05 & .411 & 29 \\
\hline 15 & $\begin{array}{l}\text { Home } \\
\text { study }\end{array}$ & 3.27 & 1.296 & 23 & 3.02 & 1.212 & 24 & 3.14 & 1.257 & 24 \\
\hline 16 & $\begin{array}{l}\text { Reading } \\
\text { stories or } \\
\text { listening to } \\
\text { it through } \\
\text { day }\end{array}$ & 4.60 & 1.248 & 11 & 4.58 & 1.109 & 8 & 4.59 & 1.175 & 10 \\
\hline 17 & $\begin{array}{l}\text { Drawing } \\
\text { and } \\
\text { coloring } \\
\text { through the } \\
\text { day }\end{array}$ & 3.95 & 1.355 & 19 & 3.39 & 1.301 & 21 & 3.65 & 1.355 & 19 \\
\hline 18 & $\begin{array}{l}\text { Listening to } \\
\text { radio }\end{array}$ & 5.17 & 1.213 & 3 & 4.94 & 1.412 & 4 & 5.05 & 1.326 & 3 \\
\hline 19 & $\begin{array}{l}\text { Relatives } \\
\text { visits }\end{array}$ & 2.56 & 1.846 & 26 & 2.61 & 1.784 & 26 & 2.58 & 1.812 & 26 \\
\hline 20 & $\begin{array}{l}\text { Helping } \\
\text { family } \\
\text { members }\end{array}$ & 3.60 & 1.584 & 20 & 3.54 & 1.569 & 20 & 3.57 & 1.575 & 20 \\
\hline 22 & $\begin{array}{l}\text { Going to } \\
\text { the mosque } \\
\text { with one of } \\
\text { the parents. }\end{array}$ & 4.56 & 1.482 & 12 & 5.31 & 1.182 & 2 & 4.96 & 1.382 & 4 \\
\hline 22 & $\begin{array}{l}\text { Performing } \\
\text { acts of } \\
\text { worship } \\
\text { (such as } \\
\text { reading the } \\
\begin{array}{l}\text { Koran, or } \\
\text { prayer) }\end{array}\end{array}$ & 4.46 & 1.271 & 14 & 4.40 & 1.330 & 11 & 4.43 & 1.302 & 12 \\
\hline 23 & $\begin{array}{l}\text { Having } \\
\text { meals }\end{array}$ & 4.24 & 1.052 & 16 & 4.09 & 1.103 & 18 & 4.16 & 1.081 & 17 \\
\hline 24 & $\begin{array}{l}\text { Having } \\
\text { bath } \\
\text { taking } \\
\text { shower }\end{array}$ & 4.71 & .875 & 8 & 4.53 & .983 & 9 & 4.62 & .937 & 8 \\
\hline 25 & $\begin{array}{l}\text { Singing } \\
\text { songs }\end{array}$ & 4.72 & 1.229 & 7 & 4.18 & 1.350 & 17 & 4.43 & 1.321 & 13 \\
\hline 26 & $\begin{array}{l}\text { Using } \\
\text { toilets }\end{array}$ & 4.78 & 1.123 & 6 & 4.78 & 1.045 & 6 & 4.78 & 1.082 & 7 \\
\hline 27 & Helping & 4.69 & 1.511 & 10 & 4.28 & 1.688 & 15 & 4.47 & 1.619 & 11 \\
\hline
\end{tabular}




\begin{tabular}{|l|l|l|l|l|c|c|c|c|c|c|}
\hline No & Paragraph & \multicolumn{2}{|l|}{ Males } & \multicolumn{2}{|l|}{ Females } & \multicolumn{2}{l|}{ Total } & \\
\hline & $\begin{array}{l}\text { little } \\
\text { siblings }\end{array}$ & & & & & & & & & \\
\hline $\mathbf{2 8}$ & $\begin{array}{l}\text { Go } \\
\text { hopping } \\
\text { with family }\end{array}$ & 3.42 & 1.652 & 1 & 3.26 & 1.555 & 21 & 3.34 & 1.601 & 21 \\
\hline $\mathbf{2 9}$ & Crying & 5.08 & 1.133 & 4 & 4.82 & 1.216 & 5 & 4.94 & 1.184 & 5 \\
\hline
\end{tabular}

The results of this question show that males are more active in the kindergarten than females.

The most practiced activity was answering phones with average (5.61) and a standard deviation (0.90), followed by staying alone for some time with average (5.30) and a standard deviation (1.07), followed by listening to songs with average (5.17) and a standard deviation (1.21), while the highest activity came with the females in the distribution of time answering calls average (5.42) and standard deviation (1.09), followed by the performance of worship with average (5.31) and standard deviation (1.18), followed by staying alone for some time with average (5.23) and standard deviation (1.13), and the sample as a whole came in first answering calls average(5.51) and standard deviation (1.01) and in the second place to stay alone for some time with average(5.26) and standard deviation (1.10) came in third place listen to songs with average (5.05) and standard deviation (1.33).

Due to the nature of the society and the developments it has witnessed, the children' distribution of time was different. Many of them spend a long time in using phones, watching $\mathrm{TV}$, or play alone, and prefer to do better activities such as drawing, painting, going out, and visiting relatives.

This shows that there is inappropriate distribution of the kindergarten kid's time. It is a sign of the need for these children and their parents to modify this distribution.

There are no previous studies that have addressed the kindergarten. But previous studies have shown mostly that time management is the average of individuals, including Saber study (2015), and that there is a difference in the organization of time and private study habits and is different between males and females in favor of females to males in the study (2008).

The second question: What is the healthy behavior level among the KG children in Jeddah according to gender?

Answering this question requires calculating the arithmetic means and standard deviations among the children from the viewpoint of mothers to practice healthy behavior and arranging their viewpoints due to gender, as shown in Table 3. 
Table 3. Arithmetic means and standard deviations among children in the level of health behavior according to gender

\begin{tabular}{|c|c|c|c|c|c|c|c|c|c|c|}
\hline & paragraph & Males & & & Female & & & Total & & \\
\hline & & Mean & St. D & Level & M. & St. D & Level & M & St. D & Level \\
\hline 11 & $\begin{array}{l}\text { Sleep well (8- } \\
9 \text { hours) a day }\end{array}$ & 1.12 & .343 & low & 1.16 & .379 & low & 1.14 & .363 & low \\
\hline 22 & $\begin{array}{l}\text { Brushes hi } \\
\text { teeth }(2-3 \\
\text { times }) \text { a day }\end{array}$ & 1.66 & .577 & low & 1.62 & .583 & low & 1.64 & .580 & low \\
\hline 33 & $\begin{array}{l}\text { Eating healthy } \\
\text { food }\end{array}$ & 1.45 & .531 & low & 1.53 & .582 & low & 1.49 & .559 & low \\
\hline 44 & $\begin{array}{l}\text { Having }(3-4) \\
\text { meals per day }\end{array}$ & 1.42 & .621 & low & 1.47 & .642 & low & 1.44 & .632 & low \\
\hline 55 & $\begin{array}{l}\text { Agrees to eat } \\
\text { less sweet }\end{array}$ & 1.83 & .608 & medium & 1.84 & .655 & medium & 1.83 & .633 & medium \\
\hline 66 & $\begin{array}{l}\text { Is keen to } \\
\text { change his } \\
\text { underwear } \\
\text { every two } \\
\text { days }\end{array}$ & 1.10 & .344 & low & 1.08 & .316 & low & 1.09 & .329 & low \\
\hline 77 & $\begin{array}{l}\text { Drinking milk } \\
\text { for once per } \\
\text { day }\end{array}$ & 1.40 & .626 & low & 1.48 & .671 & low & 1.44 & .651 & low \\
\hline 88 & $\begin{array}{l}\text { Use spoon } \\
\text { properly in } \\
\text { eating }\end{array}$ & 1.12 & .346 & low & 1.11 & .368 & low & 1.11 & .358 & low \\
\hline 99 & $\begin{array}{l}\text { Using toilets } \\
\text { without help }\end{array}$ & 1.12 & .346 & low & 1.13 & .346 & low & 1.12 & .346 & low \\
\hline 110 & $\begin{array}{l}\text { Expresses his } \\
\text { need to use the } \\
\text { toilet in time }\end{array}$ & 1.08 & .291 & low & 1.07 & .296 & low & 1.08 & .293 & low \\
\hline 111 & $\begin{array}{l}\text { Cleans himself } \\
\text { after using the } \\
\text { toilet }\end{array}$ & 1.22 & .471 & low & 1.20 & .446 & low & 1.21 & .458 & low \\
\hline 12 & $\begin{array}{l}\text { Taking off his } \\
\text { clothes before } \\
\text { using the } \\
\text { toilets }\end{array}$ & 1.04 & .200 & low & 1.05 & .237 & low & 1.05 & .220 & low \\
\hline 13 & $\begin{array}{l}\text { Wearing his } \\
\text { clothes after } \\
\text { using } \\
\text { toilets }\end{array}$ & 1.16 & .412 & low & 1.13 & .399 & low & 1.15 & .405 & low \\
\hline 14 & $\begin{array}{l}\text { Brushes his } \\
\text { hair alone }\end{array}$ & 1.61 & .693 & low & 1.96 & .678 & medium & 1.80 & .706 & medium \\
\hline 15 & $\begin{array}{l}\text { Change his } \\
\text { dirty clothes } \\
\text { regularly }\end{array}$ & 1.17 & .454 & low & 1.14 & .409 & low & 1.15 & .430 & low \\
\hline 16 & Can across the & 2.51 & .671 & phigh & 2.73 & .556 & high & 2.63 & .622 & high \\
\hline
\end{tabular}




\begin{tabular}{|c|c|c|c|c|c|c|c|c|c|c|}
\hline & paragraph & Males & & & Female & & & Total & & \\
\hline & street alone & & & & & & & & & \\
\hline 17 & $\begin{array}{l}\text { Wandering in } \\
\text { the nearby } \\
\text { house area } \\
\text { without being } \\
\text { lost }\end{array}$ & 2.55 & .779 & high & 2.67 & .666 & high & 2.61 & .723 & high \\
\hline 18 & $\begin{array}{l}\text { Walking up } \\
\text { and down } \\
\text { stairs alone }\end{array}$ & 1.27 & .605 & low & 1.29 & .631 & low & 1.28 & .619 & low \\
\hline 19 & $\begin{array}{l}\text { Clean his nose } \\
\text { with tissues }\end{array}$ & 1.20 & .414 & low & 1.15 & .372 & low & 1.18 & .392 & low \\
\hline 20 & $\begin{array}{l}\text { Spits in the } \\
\text { provided } \\
\text { space }\end{array}$ & 1.90 & .954 & low & 1.75 & .944 & medium & 1.82 & .951 & medium \\
\hline 21 & $\begin{array}{l}\text { Uses } \\
\text { appropriate } \\
\text { clothes for } \\
\text { temperature }\end{array}$ & 1.43 & .602 & low & 1.47 & .594 & low & 1.45 & .598 & low \\
\hline 222 & $\begin{array}{l}\text { puts a suitable } \\
\text { cover when } \\
\text { sleeping }\end{array}$ & 1.51 & .748 & low & 1.46 & .681 & low & 1.49 & .713 & low \\
\hline 23 & $\begin{array}{l}\text { Wearing } \\
\text { proper } \\
\text { sleeping } \\
\text { clothes }\end{array}$ & 1.13 & .403 & low & 1.12 & .383 & low & 1.13 & .392 & low \\
\hline 24 & $\begin{array}{l}\text { Washes his } \\
\text { hands before } \\
\text { eating }\end{array}$ & 1.23 & .452 & low & 1.26 & .493 & low & 1.25 & .474 & low \\
\hline 25 & $\begin{array}{l}\text { Washes his } \\
\text { hands after } \\
\text { eating }\end{array}$ & 1.10 & .306 & low & 1.10 & .307 & low & 1.10 & .306 & low \\
\hline 26 & $\begin{array}{l}\text { Take into } \\
\text { account the } \\
\text { safety aspects } \\
\text { when playing } \\
\text { with his toys }\end{array}$ & 1.44 & .545 & low & 1.51 & .550 & low & 1.48 & .548 & low \\
\hline 27 & $\begin{array}{l}\text { Eats food in } \\
\text { proper time }\end{array}$ & 1.59 & .659 & low & 1.65 & .693 & low & 1.62 & .677 & low \\
\hline 28 & $\begin{array}{l}\text { Wrap his } \\
\text { shoes alone }\end{array}$ & 1.71 & .734 & medium & 1.76 & .767 & medium & 1.74 & .751 & medium \\
\hline 29 & $\begin{array}{l}\text { Wear his shoes } \\
\text { alone }\end{array}$ & 1.28 & .520 & low & 1.22 & .422 & low & 1.25 & .471 & low \\
\hline 30 & $\begin{array}{l}\text { Take of his } \\
\text { shoes alone }\end{array}$ & 1.12 & .362 & low & 1.06 & .257 & low & 1.09 & .312 & low \\
\hline 31 & $\begin{array}{l}\text { Carry heavy } \\
\text { things } \\
\text { properly }\end{array}$ & 11.54 & .577 & low & 1.64 & .646 & low & 1.59 & .616 & low \\
\hline 32 & Sitting & 11.55 & .576 & low & 1.65 & .596 & low & 1.60 & .588 & low \\
\hline
\end{tabular}




\begin{tabular}{|c|c|c|c|c|c|c|c|c|c|c|}
\hline & paragraph & Males & & & Females & & & Total & & \\
\hline & $\begin{array}{l}\text { suitably 3- } \\
\text { meter distance } \\
\text { away from the } \\
\text { TV }\end{array}$ & & & & & & & & & \\
\hline 333 & $\begin{array}{l}\text { Do not spend } \\
\text { in front of a } \\
\text { computer } \\
\text { screen more } \\
\text { than two hours } \\
\text { a day }\end{array}$ & 11.51 & .702 & low & 11.61 &. .711 & low & 11.56 & .708 & low \\
\hline 34 & $\begin{array}{l}\text { Prefer } \\
\text { speaker-on } \\
\text { than speaker- } \\
\text { off in using } \\
\text { cellphone }\end{array}$ & 22.12 &. .827 & medium & 22.21 &. .835 & medium & 22.17 &. .832 & medium \\
\hline 35 & $\begin{array}{l}\text { Take a shower } \\
\text { alone }\end{array}$ & 2.10 & .786 & medium & 2.21 & .758 & medium & 2.16 & .772 & medium \\
\hline 36 & $\begin{array}{l}\text { Keen on } \\
\text { taking } \\
\text { medication } \\
\text { alone when } \\
\text { diseased }\end{array}$ & 2.46 & .713 & high & 2.39 & .769 & high & 2.42 & .744 & high \\
\hline 37 & $\begin{array}{l}\text { Ask to trim his } \\
\text { nails each } \\
\text { period }\end{array}$ & 1.78 & .781 & medium & 1.75 & .770 & medium & 1.76 & .774 & medium \\
\hline 38 & $\begin{array}{l}\text { expresses his } \\
\text { need to go to } \\
\text { the doctor } \\
\text { when feeling } \\
\text { sick }\end{array}$ & 1.81 & .772 & medium & 1.71 & .743 & medium & 1.76 & .758 & medium \\
\hline 39 & $\begin{array}{l}\text { keen to move } \\
\text { away from } \\
\text { touching } \\
\text { harmful } \\
\text { insects } \\
\text { animals }\end{array}$ & 1.33 & .553 & low & 1.27 & .548 & low & 1.30 & .551 & low \\
\hline \multirow[t]{2}{*}{40} & $\begin{array}{l}\text { Careful not to } \\
\text { eat anything } \\
\text { that not } \\
\text { significant to } \\
\text { health }\end{array}$ & 11.93 & .746 & medium & 1.91 & .698 & medium & 1.92 & .720 & medium \\
\hline & $\begin{array}{l}\text { Total score of } \\
\text { health } \\
\text { behavior }\end{array}$ & 11.5155 &. .17610 & low & 11.5380 & .17160 & low & 11.5274 & 17392 & low \\
\hline
\end{tabular}

Table (3) shows that the health behavior of males and females was generally low, where it was among males with average (1.52) with a standard deviation (0.18), and the females with average (1.54) and standard deviation (0.17). The general degree of healthy behavior was (1.53) and standard deviation (0.17). The least four healthy behaviors - need to be take care of 
the male- were: wash hands after eating, take off his clothes alone before using the toilet, express their needs to use the toilet in time, and keen to change his underwear every two days. While the top three health behaviors males had were: keen on taking medication alone when ill, can cross the street safely alone, and wandering in the nearby area of the house without being lost.

While the less healthy behaviors for the females were: expressing needs to use the toilet in time, keen to change her underwear every two days, take off her shoes alone, and take off her clothes alone before using the toilet. The highest healthy behaviors among females were: keen on taking medication alone when ill, can cross the street safely alone, wandering in the nearby area of the house without being lost.

The least healthy behaviors for the whole sample were expressing needs to use the toilet in time, keen to change his underwear every two days, take off his shoes alone, and take off his clothes alone before using the toilet. The highest healthy behaviors among respondents as a whole were: keen on taking the medicine alone when ill, can cross the street safely alone, wandering in the nearby area of the house without being lost.

The possess of high health behaviors in some things and low in the others is that the child at this age still need more health care even if he is possessing those different behaviors that play a role in increasing self-confidence and is working to bring it to the concept of a more positive and become later more independent .

There are no previous studies that have addressed this subject at the kindergarten. Some studies have indicated that the pattern of food on the elementary stage children where breakfast neglected as a study, Saleh (2006). Elementary school students have a pattern of behavior suitable as a study for Jaffery (2008). Possession of health behavior to a high degree of individuals, this is a study by Al-Amamy (2011).

The only difference were in (Emine \& Dundar, 2011) study that age, grade, and gender have a role to have a healthy behavior.

The third question: Is there a relationship between the KG children time distribution with the healthy behavior in Jeddah?

To answer this question, Pearson correlation coefficient was calculated to identify if there is a relationship between the increase in the specified activity and the health behavior. The following table shows the results.

Table 4. The correlation of the time distribution among KG children with the total health behavior

\begin{tabular}{|l|l|c|c|l|}
\hline N. & \multicolumn{1}{|c|}{ Paragraph } & $\begin{array}{c}\text { correlation } \\
\text { coefficient }\end{array}$ & $\begin{array}{c}\text { The significance } \\
\text { level }\end{array}$ & \multicolumn{1}{|c|}{ Significance } \\
\hline 1 & Watching T.V all day & 0.01 & 0.79 & Not significant \\
\hline 2 & $\begin{array}{l}\text { Using the internet; songs, games and apps } \\
\text { all day }\end{array}$ & $0.08-$ & 0.08 & Not significant \\
\hline
\end{tabular}




\begin{tabular}{|c|c|c|c|c|}
\hline 3 & Answering calls through day & 0.03 & 0.52 & Not significant \\
\hline 4 & $\begin{array}{l}\text { Using the phone or using it as a game all } \\
\text { the day }\end{array}$ & 0.09 & 0.05 & Not significant \\
\hline 5 & Playing with the computer & $0.03-$ & 0.57 & Not significant \\
\hline 6 & Playing with a ball or a game & 0.09 & 0.05 & Not significant \\
\hline 7 & Playing alone & $0.12-* *$ & 0.01 & Negatively significant \\
\hline 8 & Playing with others & $0.15 * *$ & 0.001 & Positively significant \\
\hline 9 & $\begin{array}{l}\text { Talking to the parents or chat with family } \\
\text { groups }\end{array}$ & $0.18^{* *}$ & 0.00 & Positively significant \\
\hline 10 & Trips & 0.02 & 0.61 & Not significant \\
\hline 11 & Hanging out with friends & 0.03 & 0.50 & Not significant \\
\hline 12 & Staying alone for some times & $0.07-$ & 0.13 & Not significant \\
\hline 13 & Day sleep & $0.09-*$ & 0.04 & Negatively significant \\
\hline 14 & Night sleep & $0.14 * *$ & 0.002 & Positively significant \\
\hline 15 & Learning at home & $0.18 * *$ & 0.00 & Positively significant \\
\hline 16 & $\begin{array}{l}\text { Reading stories or listening to them } \\
\text { throughout the day }\end{array}$ & $0.11 *$ & 0.01 & Positively significant \\
\hline 17 & Drawing and coloring through the day & 0.07 & 0.12 & Not significant \\
\hline 18 & Listening to the radio in his free time & 0.09 & 0.053 & Not significant \\
\hline 19 & Visiting relatives & 0.08 & 0.06 & Not significant \\
\hline 20 & Helping family members & $0.13 * *$ & 0.004 & Positively significant \\
\hline 22 & Going to the mosque with parents & 0.06 & 0.17 & Not significant \\
\hline 22 & $\begin{array}{l}\text { Worshiping time( praying and reading } \\
\text { Quran) }\end{array}$ & $0.16^{*}$ & 0.00 & Positively significant \\
\hline 23 & Having meals & 0.07 & 0.11 & Not significant \\
\hline 24 & $\begin{array}{l}\text { Having shower and playing while } \\
\text { showering. }\end{array}$ & 0.00 & 0.99 & Not significant \\
\hline 25 & Singing songs & 0.04 & 0.36 & Not significant \\
\hline 26 & Using toilets per day & $0.03-$ & 0.46 & Not significant \\
\hline 27 & Helping his little siblings & $0.11 *$ & 0.010 & Positively significant \\
\hline 28 & Go shopping with parents & 0.05 & 0.31 & Not significant \\
\hline 29 & Crying & $*_{-}-0.18$ & 0.00 & Negatively significant \\
\hline
\end{tabular}

It has been observed from previous study that there is some behavior that does not affect the children. While some other behaviors that increase their health behavior, namely: to play with others, and talk with parents, sitting in bed before going to sleep, learning at home, reading stories, help family members, perform acts of worship and help younger siblings. Other behaviors had the most important behaviors that reduce health behavior in children from the viewpoint of mothers were: playing alone, sleeping during the day and crying.

This indicates that the family should relief such behaviors; crying, play alone and reduce the hours of sleeping during the day, Because it will be reflected on the health behavior of the 
children in a negative way. While necessary to increase the behaviors of a play with others, sit in bed before going to sleep, talk with the parents, learning at home, reading stories, helping family members, performing acts of worship and help the young siblings.

The fourth question: Does the healthy behavior differ depending on the educational level of the KG children's parents in Jeddah? To answer this question the one-way analysis of variance (ANOVA) has been used, and the results shown in the Table (4):

Table 5. Results of the variance of the differences between the arithmetic means to measure health behavior depending on the level of education of parents

\begin{tabular}{|c|c|c|c|c|c|c|}
\hline The variable & Source of variance & Squares sum & $\begin{array}{l}\text { Freedom } \\
\text { degree }\end{array}$ & $\begin{array}{l}\text { Squares } \\
\text { mean }\end{array}$ & F value & $\begin{array}{l}\text { significanc } \\
\text { e level }\end{array}$ \\
\hline \multirow{3}{*}{$\begin{array}{l}\text { The father's } \\
\text { educational level }\end{array}$} & Between groups & .192 & 3 & .064 & 2.128 & .096 \\
\hline & Within groups & 15.295 & 509 & .030 & & \\
\hline & Total & 15.487 & 512 & & & \\
\hline \multirow{3}{*}{$\begin{array}{l}\text { The mother's } \\
\text { educational level }\end{array}$} & Between groups & .019 & 3 & .006 & .210 & .890 \\
\hline & Within groups & 15.468 & 509 & .030 & & \\
\hline & Total & 15.487 & 512 & & & \\
\hline
\end{tabular}

From the Table (5) it has been concluded that there were no statistically significant differences in health behavior differences depending on the father's and the mother education level on a kindergarten child, reaching values of $\mathrm{P}(2.13,0.21)$, respectively, and all these values are not statistically significant at the level of significance $(\alpha=0.05)$.

The parents, regardless of their level of education, are careful to take care of their children, especially in this age- they take care of the physical aspects, and make great effort to help their children to prevent physical problems that can affect them. A child perhaps needs the impact of education in the choice of profession or professional status, but the culture make it easy to get, regardless of education, due to the availability of various means of technology.

\section{Recommendations:}

Based on the conclusion of this study, the researcher suggests the following points:

a) Teachers and mothers should take care of the children in order to change their time distribution to be exploited properly.

b) Teachers and mothers should be guided to reduce some unsuitable healthy behaviors of children such as washing hands after meals, using toilets, changing underwear and taking off shoes.

c) Teachers and mothers should guide the children to avoid playing alone, long day sleep and crying.

d) Enhance parents' awareness about time distribution and healthy behavior for $\mathrm{KG}$ children. 
e) Conduct more studies about time distribution and healthy behavior.

f) Take advantage of the time distribution and healthy behavior scale in order to be applied on the children and carry out field studies to diagnose child problems.

g) Take advantage of the study to develop counseling programs for mothers regarding time distribution and train them for the ways that would help their children acquire healthy behaviors.

h) Organize a conference in Jeddah on kindergartens to be attended by faculty members, teachers and mothers to discuss the healthy behaviors and time distribution of children.

\section{References}

Ahmed, Mazin, Al-Nafaakh, Nizar al-Janabi, Salman (2008). Healthy behavior and trends in athletes. Journal of Physical Education Sciences. 7 (1) 0.86 to 121.

Al-Alaaq, Bashir (2009). The basics of time management. Amman: Dar Yazouri scientific publication and distribution.

Al-Amamy, Bassam (2007). The level of health awareness and the degree of health practices of basic school students in the schools of the Governorate of Ma'an. Journal of College of Education, Al-Azhar University 0.145 (1) 0.119 to 149.

Aliya, Muhammad (2008). Time management habits among school tenth and eleventh grade students, and its relationship to their gender and academic specialization in Madaba, Irbid Journal for Research and Studies, Jordan, 11 (2).

Al-Suoef, Ahmed (2014). Time Management Strategies among students of the Faculty of Educational Sciences at the University of Jordan. Studies, Educational Sciences, 41 (2) from 0.960 to 973 .

Bakhit, Mohammed (2008). The behavior of time management and its relationship to the locus of control and ability predictive academic achievement through some variables among university students. Journal of the Faculty of Education, Ain Shams University 0.32 (3) from 0.430 to 503 .

Beetle, Leicester. (1999) Time management. Translation, Mohammad Najjar. Oman: National Publishing and Distribution.

Emine, G \& Dundar, G (2011). Turkish adolescent health risk behaviors and self-esteem, Social behavior and personality, 39(2), 219-228.

Harvey, V., Chickie-Wolf, Louise A. \& Eads, James B. (2007). Fostering independent learning: Practical strategies to promote student success. The Guilford practical intervention in the schools series (ERIC ED 494217).

Harvey, V., Chickie-Wolf, Louise A. \& Eads, James B. (2007). Fostering indecent learning: Practical strategies to promote student success. The Guilford practical intervention in the schools series (ERIC ED 494217)

Hilal, Abdul Rahman al-Husseini, Nadia (2004). Some psychological variables contribute to 
the time management at the university students. Education (Azhar University) 0.125 (1) 0.189 to 271 .

Jaffery, Ali (2008). Measure the level of health behavior among students of the last three grades primary school in Riyadh. The scientific journal, Faculty of Physical Education, Minia University.

Kearns, H \& Gardiner, M (2007). Is it time well spent? The relationship between time management behaviors effectiveness, work-related morale and distress in a university context. Higher education research and development, 26(2), 235-247.

Khalifa, Ghazi (2012). Some family variables effect at the school time administration habits in the first grade secondary students in Madaba, Jordan. Journal of Educational and psychological sciences, 13 (2) from 0.485 to 512.

Mashaan, Sultan, Owed and Khalifa, Abdul Latif Mohammed (1999). Substance abuse affecting the nerves between Kuwait University students, the journal Psychological Service and Development Conference, Kuwait, Kuwait University.

Mohammed, Sahar (2004). Effective recreational program to acquire some behaviors athlete environmental awareness to kindergarten children. Unpublished $\mathrm{PhD}$ thesis, Faculty of Physical Education, Tanta University.

Radwan, Samer Gamiel, Reshch, Conrad, (2001). The healthy behavior and trends toward health field Study comparison between the Syrian and German students.

Saber, Nian (2015). Time management at university students and its relationship with some variables. Amarrapak, a scientific journal published by the American Academy of Arab Science and Technology 0.17 (6) 0.33 to 50.

Saleh, Ali Saleh, Zena (2013). Academic procrastination and time management relationship with the students of the Faculty of Education. Arab Studies in Education and Psychology. 38 (2) from 0.243 to 271.

Saleh, Yahya (2006). Food style for elementary school students in Riyadh. General Administration of School Health, Ministry of Education.

Severt, Luther (2007). If you're in a hurry slow down, translated by Mohammad Askiv, Riyadh: Obeikan Library.

Shaheen, Mohammad (2007). The development of time management skills and selfmanagement through the pressures of work. A working paper submitted in the development of leadership skills for managers of public and private business organizations Symposium, Cairo, Arab Republic of Egypt.

Shukri, Maysa (1999). Healthy behavior patterns as methods to cope with hardship situations. Psychological studies. 9 (4) 0.559 to 584.

Smadi, Ahmad Samadi, Muhammad. (2011). Healthy behavior for students in Jordanian universities scale, Arab Journal of Psychiatry 0.22 (1) 0.83 to 88. 


\section{Macrothink}

International Research in Education

ISSN 2327-5499

2017, Vol. 5, No. 1

Tuffaha, (2006), time management skills and personal factors and the pattern of behavior among a sample of graduate students, the educational and psychological research magazine, Monofia 0.3 (21) 0.55 to 92 .

\section{Copyright Disclaimer}

Copyright reserved by the authors.

This article is an open-access article distributed under the terms and conditions of the Creative Commons Attribution license (http://creativecommons.org/licenses/by/3.0/). 